\title{
Bioconcentration of Lead and x-ray Microanalysis with SEM in the Freshwater Rotifer Lecane quadridentata (Rotifera: Monogononta)
}

\author{
Jesús Alvarado-Flores ${ }^{1}$, Roberto Rico-Martínez ${ }^{2 *}$ \\ ${ }^{1}$ Catedrático CONACYT / Unidad de Ciencias del Agua, Centro de Investigación Científica de Yucatán \\ A.C. Cancún, Quintana Roo, México \\ ${ }^{2}$ Universidad Autónoma de Aguascalientes, Centro de Ciencias Básicas, Departamento de Química, \\ Avenida Universidad 940, Aguascalientes, Ags., CP 20131, México
}

Received: 6 October 2016

Accepted: 23 November 2016

\begin{abstract}
We studied the accumulation of lead as $\mathrm{Pb}\left(\mathrm{NO}_{3}\right)_{2}$ in the freshwater rotifer Lecane quadridentata using Leadmium Green and x-ray microanalysis by energy dispersion. The results indicate that lead is bioaccumulated in great amounts in the stomach after the rotifer is exposed for $24 \mathrm{~h}$ to $0.5 \mathrm{mg} \mathrm{L}^{-1}$ of $\mathrm{Pb}\left(\mathrm{NO}_{3}\right)_{2}$. When the exposure concentration of $\mathrm{Pb}\left(\mathrm{NO}_{3}\right)_{2}$ is increased to $1.0 \mathrm{mg} \mathrm{L}^{-1}$, lead was detected mostly in the cuticle after $24 \mathrm{~h}$. Analysis of x-ray microanalysis by energy dispersion suggests a loss of calcium and rubidium, and an increase of aluminum, niobium, and silicon. A discussion comparing bioaccumulation between the rotifers Brachionus calyciflorus and Lecane quadridentata is included.
\end{abstract}

Keywords: aquatic toxicology, environmental toxicology, zooplankton, metals

\section{Introduction}

The accumulation of metals depends on: a) the biological species and the chemical element considered, b) the exposure regimen applied, c) cation homeostasis mechanisms, d) life-cycle influences on metal accumulation, and e) an appropriate experimental design in different spatial and temporal scales [1]. Lead is present in environmental matrices and originates from anthropogenic sources, production of batteries, cables,

*e-mail: rrico@correo.uaa.mx pigments, and chemical additives, mining industries, refineries, and waste disposal [2]. Lead can be removed from the atmosphere and transferred to environmental surfaces and compartments by wet or dry deposition, and when deposited in water, lead partitions rapidly between the sediment and aqueous phases [2]. The distribution of lead within animals is closely associated with calcium metabolism. It is interesting that the tetravalent organic form of lead is generally more toxic than the divalent, inorganic form, and its distribution in organisms may not specifically follow calcium metabolism [3].

Lead enters cells through membrane transporters of divalent cations, potassium channels, cholinergic 
receptors, and mono and polyvalent channels of calcium; the affinity of lead for calcium channels is determined by four residues of glutamate, and enters the cell through an electrostatic interaction between the carboxyl groups of the lateral chains of glutamate [4].

Lead is known to alter biochemical processes and is accumulated in tissues in the freshwater rotifer Brachionus calyciflorus, lead produced decalcification after 24-h exposure at $1.0 \mathrm{mg} \mathrm{L}^{-1}$ [5]. In a five-day chronic toxicity test using Lecane quadridentata there was a $44 \%$ reduction in real concentrations of $\mathrm{Pb}\left(\mathrm{NO}_{3}\right)_{2}$ (determined by atomic absorption) from day 0 to day 5 as a consequence of rotifer uptake [6]. In contrast, the $\mathrm{Pb}$ concentration in EPA medium decreased $52.6 \%$ in $24 \mathrm{~h}$ according to atomic absorption results in the rotifer $B$. calyciflorus when compared to $\mathrm{EPA}+\mathrm{Pb} / 24 \mathrm{~h}$ versus $\mathrm{EPA}+\mathrm{Pb} / 24 \mathrm{~h}$ residual $\mathrm{Pb}$ after rotifer accumulation [5]. This difference suggests either important differences in the detoxification activities or bioconcentration in both species of rotifers.

In rotifers, metal detection in specific places of the rotifer anatomy is scarce; recently, in two species of rotifers trivalent and hexavalent chromium were found after having accumulated in the cuticle of Lecane quadridentata and Brachionus calyciflorus [7]. Therefore, the present study aims to analyze the accumulation of lead in the cuticle of the freshwater rotifer Lecane quadridentata using Leadmium Green to follow the entry of lead after early contact with the rotifer, and then x-ray microanalysis by energy dispersion (through a scanning electron microscope) to study the elemental composition of the rotifers exposed to lead. Finally, we would discuss the differences in lead accumulation and their effects between two freshwater rotifer species: B. calyciflorus and L. quadridentata.

\section{Experimental}

The freshwater rotifer Lecane quadridentata were cultured in a bioclimatic chamber with a 16/8 dark/light period at $25^{\circ} \mathrm{C}$ [8]. Rotifers were kept in Petri dishes with EPA medium [9] and fed the green alga Nannochloris oculata (strain LB2194 of the University of Texas Collection) grown in Bold's basal medium [10].

Energy-dispersive $\mathrm{x}$-ray microanalysis by scanning electron microscopy is used to determine the elemental concentration of aluminum, calcium, carbon, gold, lead, niobium, oxygen, rubidium, and silicon, and all rotifers intoxicated and not intoxicated were used for determining lead by $\mathrm{x}$-rays with SME and Leadmium Green AM dye, according to the protocol of Alvarado-Flores et al. [5]. For x-ray determination we intoxicated 100 rotifers with $1.0 \mathrm{mg} \mathrm{L}^{-1}$ of $\mathrm{Pb}\left(\mathrm{NO}_{3}\right)_{2}$, and another group of 100 rotifers were used as a non-toxic control (the experiments took place in a 24-well polystyrene plate with a final volume of $2 \mathrm{~mL}$ in standard culture conditions). Then we collected the control group and the intoxicated group of rotifers and placed them in an Eppendorf tube in a final volume of $1 \mathrm{~mL}$ of EPA medium and added $100 \mu \mathrm{l}$ of $3 \%$ formaldehyde. Then the samples were coated with gold using a DESK II camera, and photographed with JEOL
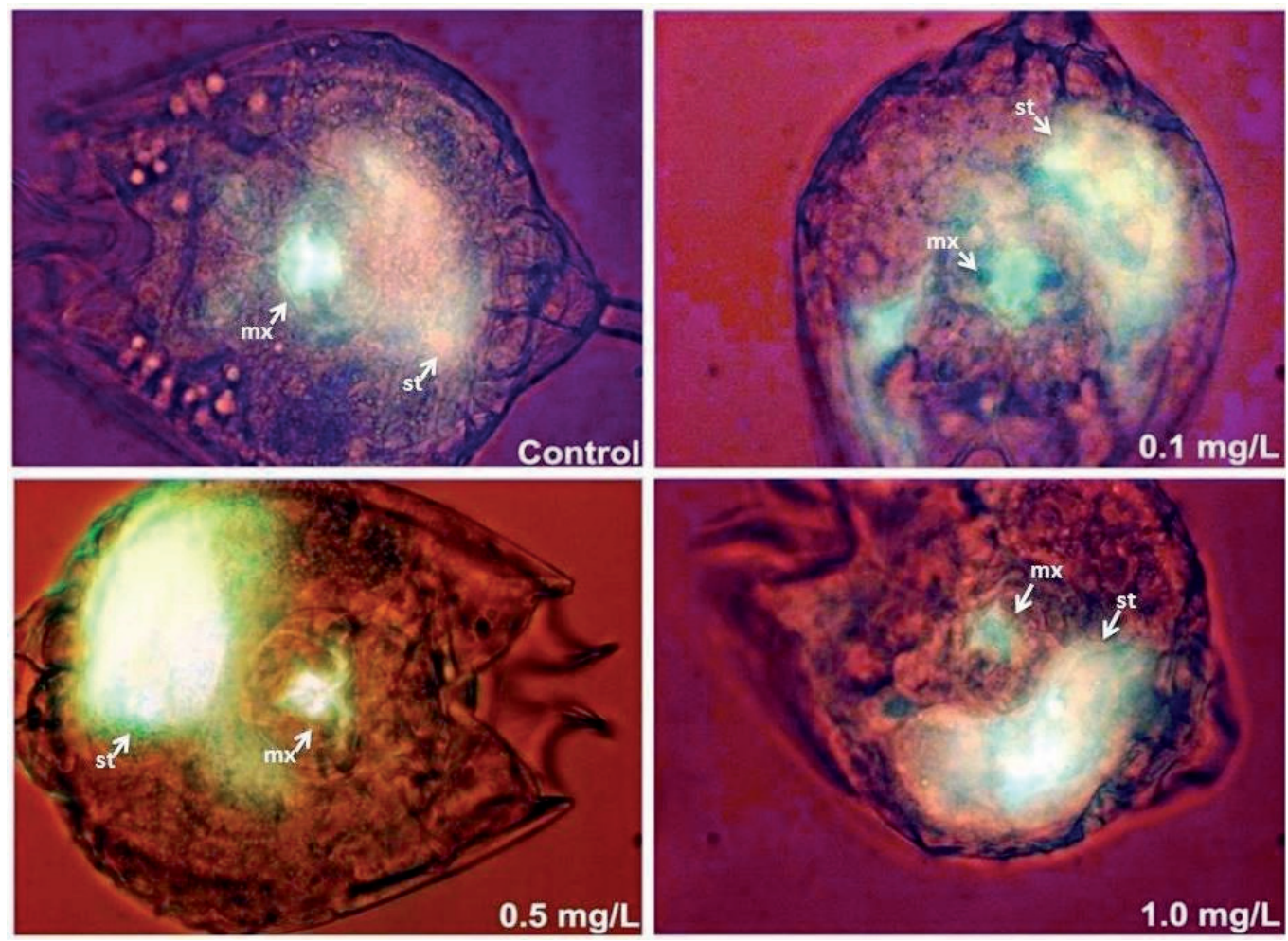

Fig. 1. Analysis of in vivo intracellular lead uptake by Leadmium Green AM dye in the rotifer Lecane quadridentata. Exposure time 24 hours, $\mathrm{st}=$ stomach, and $\mathrm{mx}=$ mastax. 
5000 LV SEM. The corresponding x-ray spectra were at $20 \mathrm{kV}$ with an acquisition time of $200 \mathrm{~s}$, working distant $10 \mathrm{~mm}$. The range of $\mathrm{x}$-ray penetration is $0-1,000 \mathrm{~nm}$. For quantitative analysis we used the commercial software INCA suite 3.04 (Oxford 2.6 statistical instrument).

The analysis of In vivo intracellular lead uptake using Leadmium Green AM was made as follows: another group of 30 rotifers was used as a control without toxic. Additionally we intoxicated rotifers $(n=30$ for each concentration) with $0.1,0.5$, and $1.0 \mathrm{mg} \mathrm{L}^{-1}$ of $\mathrm{Pb}\left(\mathrm{NO}_{3}\right)_{2}$ for 24 hours (experiments took place in a 24 -well polystyrene plate with a final volume of $2 \mathrm{~mL}$ with EPa medium). Finally, all rotifers of each group were analyzed according to the protocol of Alvarado-Flores et al. [5]. Fluorescence was determined with an excitation spectrum of 450-490 $\mathrm{nm}$ and an emission barrier of $515 \mathrm{~nm}$. The photographs were taken with the camera Cool SNAP PRO coupled to an Axioscop 40 Zeiss microscope.

\section{Results and Discussion}

The Leadmium Green study allowed us to localize $\mathrm{Pb}\left(\mathrm{NO}_{3}\right)_{2}$ in L. quadridentata after $24 \mathrm{~h}$ of exposure with different concentrations $\left(0.1,0.5\right.$, and $\left.1.0 \mathrm{mg} \mathrm{L}^{-1}\right)$. The accumulation of $\mathrm{Pb}\left(\mathrm{NO}_{3}\right)_{2}$ occurs mainly in the stomach and other parts of the digestive system and in the vitellarium (Fig. 1). In the stomach the greatest accumulation of lead occurred at an exposure concentration of $0.5 \mathrm{mg} \mathrm{L}^{-1}$ of $\mathrm{Pb}\left(\mathrm{NO}_{3}\right)_{2}$. The x-ray microanalysis showed detection of lead in L. quadridentata after $24 \mathrm{~h}$ of exposure at $1.0 \mathrm{mg}$ $\mathrm{L}^{-1} \mathrm{~Pb}\left(\mathrm{NO}_{3}\right)_{2}$ (Table 1). Also, we observed a decrease in calcium and an increase in silicon and aluminum in intoxicated rotifers when compared with control animals (Table 1). The only two elements were we found statistical significant differences in were gold and lead. Gold is used as a part of sample preparation for SEM. Both controls and intoxicated animals were prepared in the same way. Therefore, we really have no way of explaining the differences in gold content between both groups. The most important part of the manuscript is related to the significant differences between lead in the control group and the group of rotifers exposed to lead. All we can say is that the values of the elements (especially carbon and oxygen) are consistent with the values and number of replicates reported in previous works (Hernández-Ruiz et al., 2016; Alvarado-Flores et al., 2012). The presence of gold, niobium, and rubidium are related to the process of preparation of the animals for SEM, and we do not have a clear explanation of why some concentrations are higher in the control than intoxicated animals or the other way around regarding these three elements.

The main way of entry of $\mathrm{Pb}\left(\mathrm{NO}_{3}\right)_{2}$ in rotifers is through the digestive system, and absorption and adsorption takes place in the stomach. It is probably the interchange of calcium for silicon caused by $\mathrm{Pb}\left(\mathrm{NO}_{3}\right)_{2}$ exposure to a mechanism of detoxification in rotifers, as suggested by our x-ray diffraction results. The accumulation of lead in the cuticle of L. quadridentata happens after $24 \mathrm{~h}$ exposure; instead, in B. calyciflorus there is no lead accumulation after 24-h exposure at $1.0 \mathrm{mg} \mathrm{L}^{-1}$ [5]. In both species there is decalcification and an increase in silicon in the cuticle (compared to our results with those of [5]). These similarities in the effects of lead exposure in both species suggest that $\mathrm{Pb}\left(\mathrm{NO}_{3}\right)_{2}$ alters the biochemical mechanisms of transport and distribution of both calcium and silicon in the cuticle of the rotifers. Recent studies of chromium III and VI exposure in the same two species also resulted in decalcification; however, the levels of silicon behave in different ways in both species: L. quadridentata showed an increase in silicon after exposure to chromium III, but silicon was not detected after exposure to chromium VI. In B. calyciflorus, exposure to both chromium III and VI resulted in no detection of silicon [7].

All these results can be explained at the biochemical level with a scenario in which lead enters the cells and is distributed mainly through the transport of divalent cations (MTCD), potassium channels, cholinergic

Table 1. X-ray diffraction elemental analysis of composition of Lecane quadridentata organisms control and intoxicated with $\mathrm{Pb}\left(\mathrm{NO}_{3}\right)_{2}$. The values are the mean \pm one standard deviation. $\mathrm{CV} \%$ is the coefficient of variation.

\begin{tabular}{|c|c|c|c|c|}
\hline Element & $\begin{array}{c}\text { \% Composition } \\
\text { L. quadridentata } \\
\text { Control }(\mathrm{n}=8)\end{array}$ & CV\% & $\begin{array}{c}\text { \% Composition } \\
\text { L. quadridentata } \\
\text { Intoxicated Pb(NO3)2 (n=12) }\end{array}$ & CV\% \\
\hline Aluminium & $0.94 \pm 0.80$ & 85.11 & 1.79 & 0 \\
\hline Calcium & $0.52 \pm 0.09$ & 17.31 & $0.47 \pm 0.38$ & 80.85 \\
\hline Carbon & $65.07 \pm 1.47$ & 2.26 & 25.32 & 0 \\
\hline Gold & 0 & 0.00 & $2.28 \pm 1.73$ & 75.88 \\
\hline Lead & 0 & 0.00 & $20.29 \pm 17.40$ & 85.76 \\
\hline Niobium & $17.18 \pm 1.73$ & 10.07 & $30.18 \pm 8.84$ & 29.29 \\
\hline Oxygen & $29.23 \pm 6.72$ & 22.99 & $0.47 \pm 0.08$ & 17.02 \\
\hline Rubidium & $1.86 \pm 0.19$ & 10.22 & $0.78 \pm 0.38$ & 48.72 \\
\hline Silicon & $0.64 \pm 0.21$ & 32.81 & & 0.44 \\
\hline
\end{tabular}


receptors, and channels of calcium mono and polyvalents: $\mathrm{Na}^{+2}, \mathrm{~K}^{+2}, \mathrm{Ca}^{+2}, \mathrm{Si}^{+2}, \mathrm{Li}^{+2}, \mathrm{Cs}^{+2}$, and $\mathrm{Ba}^{+2}$ [4]. Once inside, the cells lead can be fixed to the cuticle or be detoxified by several mechanisms in which the differences between rotifer species explain why decalcification occurs in both species, but silicon behaves differently. Perhaps the fact that L. quadridentata has the thickest cuticle and could be benthic and B. calyciflorus has a less thick cuticle and is completely planktonic might explain the differences in observed silicon levels.

The sensitivity to $\mathrm{Pb}\left(\mathrm{NO}_{3}\right)_{2}$ between both genera and species also differ. For example, in B. calyciflorus and $B$. plicatilis the LC50 value is $4.0 \mathrm{mg} \mathrm{L}^{-1}$, while in $B$. patulus it is 6.15 . In contrast, in $L$. quadridentata the LC50 it is $3.7 \mathrm{mg} \mathrm{L}^{-1}$, in L. hamata it is 0.68 , and in $L$. luna it is $0.14 \mathrm{mg} \mathrm{L}^{-1}$ [11]. It seems by looking at the small set of data that the Brachionus species are more tolerant to lead than species of Lecane. This fact might be related to a scenario in which species of Brachionus detoxify metals better than species of Lecane. In general, the range of acute toxicity in rotifers for $\mathrm{Pb}\left(\mathrm{NO}_{3}\right)_{2}$ goes from 0.035 to $56.2 \mathrm{mg} \mathrm{L}^{-1}[12]$.

\section{Conclusions}

In conclusion, exposure to lead decalcifies the cuticle of freshwater rotifers with a related increase in silicon. Based on a small set of data, we can affirm that species of the genus Brachionus are more tolerant to lead in terms of acute toxicity, perhaps because its detoxification mechanisms are more efficient than species of the genus Lecane.

\section{Acknowledgements}

The authors wish to thank Javier Ventura-Juárez, Marcelo Silva-Briano, and Aracely Adabache for their support.

\section{References}

1. DEFOREST D.K., BRIX K.V., ADAMS W.J. Assesing metal bioaccumulation in aquatic environments: the inverse relationship between bioaccumulation factors, trhopic transfer factors and exposure concentration. Aquat Toxicol 84, 236, 2007.

2. WORLD HEALTH ORGANIZATION. Inorganic lead. Environmental Health Criteria 165. Geneva: International Programme on Chemical Safety. 1995.

3. WORLD HEALTH ORGANIZATION. Inorganic lead. Environmental health criteria 85. Geneva: International Programme on Chemical Safety. 1989.

4. GARZA A., CHÁVEZ H., VEGA R., Y SOTO E. Mecanismos celulares y moleculares de la neurotoxicidad por plomo. Salud Mental 28, 48, 2005.

5. ALVARADO-FLORES J., RICO-MARTÍNEZ R., VENTURA-JUÁREZ J., SILVA-BRIANO M., RUBIOFRANCHINI I. Bioconcentration and localization of lead in the freshwater rotifer Brachionus calyciflorus Pallas 1677 (Rotifera: Monogononta). Aquatic Toxicology 109, 127, 2012.

6. HERNANDEZ-FLORES S., AND RICO-MARTÍNEZ R. Study of the effects of $\mathrm{Pb}$ and $\mathrm{Hg}$ toxicity using a chronic toxicity reproductive 5-day test with the freshwater rotifer Lecane quadridentata. Environmental toxicology 21, 533, 2006.

7. HERNÁNDEZ-RUIZ E., ALVARADO-FLORES J., RUBIO-FRANCHINI I., VENTURA-JUÁREZ J., RICOMARTÍNEZ R. Adverse effects and bioconcentration of chromium in two freshwater rotifers species. Chemosphere 158, 107, 2016.

8. PÉREZ-LEGASPI I.A., RICO-MARTÍNEZ R. Effect of temperature and food concentration in two species of littoral rotifers. Hydrobiology 387/388, 341, 1998.

9. US. ENVIRONMENTAL PROTECTION AGENCY. In Peltier, WH, Weber CI (Eds.). Methods for measuring the acute toxicity of effluents to freshwater and marine organisms. US. Environmental Protection Agency, Washington, DC, EPA-600/485-013, 1985.

10. NICHOLS H.W. Growth media-freshwater. In: Stein R. (Ed.) Handbook of physiological methods. Cambridge University Press, 7, 1973.

11. RICO-MARTINEZ R., PÉREZ-LEGASPI I., ARIASALMEIDA J.C., SANTOS-MEDRANO G.E. Encyclopedia of Aquatic Ecotoxicology, Chapter: Rotifers in Ecotoxicology, Publisher: Springer Netherlands, Editors: Jean-François Férard, Christian Blaise. 973, 2012.

12. RICO-MARTÍNEZ R., ARZATE-CÁRDENAS M.A., ROBLES-VARGAS D., PÉREZ-LEGASPI A., ALVARADO-FLORES J., SANTOS-MEDRANO G.E. Rotifers as models in toxicity screening of chemicals and environmental samples. Experimental Models in Toxicity Screening, Dr. Marcelo Larramendy (Ed.), InTech, 2016. 